\title{
The Role of Depolarization in the Survival and Differentiation of Cerebellar Granule Cells in Culture
}

\author{
Vittorio Gallo,, ${ }^{1, a}$ Ann Kingsbury, ${ }^{1}$ Robert Balázs, ${ }^{1}$ and Ole S. Jørgensen ${ }^{2}$ \\ 'Medical Research Council, Developmental Neurobiology Unit, London WC1N 1PJ, United Kingdom, and \\ 2Psychochemistry Institute, Rigshospitalet, DK-2100 Copenhagen, Denmark.
}

Cultures greatly enriched in granule cells from early postnatal cerebellum (P8) were grown in a medium containing fetal calf serum. Under the conditions used, nerve cells died, usually within a week, unless the $K^{+}$concentration in the medium was $\geq 20 \mathrm{~mm}$. The requirement for elevated $\left[\mathrm{K}^{+}\right]$。 was manifested by about $3 \mathrm{~d}$ in vitro, and after this time continuous exposure to high $\left[\mathrm{K}^{+}\right]_{\mathrm{e}}$ was essential for the survival of the granule cells. The initial morphological and biochemical maturation of the granule cells was similar in the presence and the absence of elevated $\left[K^{+}\right]_{e}$, suggesting that the dependence on depolarizing conditions develops in parallel with the expression of the differentiated characteristics of the cells. The positive effect of elevated $\left[K^{+}\right]_{e}$ on granule cell survival was not influenced by preventing bioelectric activity in the cultures with TTX and xylocaine. On the other hand, depolarization-induced transmembrane $\mathrm{Ca}^{2+}$ flux was essential in securing the maintenance of the granule cells. Depolarized nerve cells were compromised when $\mathrm{Ca}^{2+}$ entry was blocked by elevated $\mathrm{Mg}^{2+}$, EGTA, or organic $\mathrm{Ca}^{2+}$ antagonists, while dihydropyridine $\mathrm{Ca}^{2+}$ agonists [BAY K 8644, (+)-(S)-202 791 and CGP 28392] were potent agents preventing nerve cell loss in the presence of $15 \mathrm{~mm}\left[\mathrm{~K}^{+}\right]_{e}$, which was ineffective on its own. Calmodulin inhibitors (1 $\mu \mathrm{M}$ trifluoperazine or calmidazolium) blocked the beneficial effect of $\mathrm{K}^{+}$-induced depolarization on granule cells. The comparison of the timing of the differentiation and innervation of the postmitotic granule cells in vivo with the development of the $\mathrm{K}^{+}$dependence in vitro would indicate that depolarization of the granule neurons in culture mimics the influence of the physiological stimulation in vivo through excitatory amino acid receptprs, including $\boldsymbol{N}$-methyl-D-aspartate receptors, involving $\mathrm{Ca}^{2+}$ entry and the activation of $\mathrm{a} \mathrm{Ca}^{2+}$ / calmodulin-dependent protein kinase.

There is substantial evidence indicating that bioelectric activity markedly influences the survival of nerve cells during certain stages of their development (Wiesel and Hubel, 1963; Black,

\footnotetext{
Received Aug. 26, 1986; revised Dec. 9, 1986; accepted Dec. 23, 1986.

V. G. was supported by a Long-Term EMBO Fellowship. O.S.I. received support for this work from the Danish Medical Research Council. We wish to thank Dr. B. Gähwiler (Sandoz Ltd., Basel) for helpful discussions and for providing the enantiomers of 202 791. We are indebted to Prof. E. Hoffmeister and Dr. B. Garthof(Bayer, AG), Prof. H. Brunner (CIBA-Geigy, AG), Knoll, AG, and Smith Kline \& French Ltd., for providing the calcium effectors used in this study.

Correspondence should be addressed to Dr. Robert Balázs, Medical Research Council, Developmental Neurobiology Unit, 1 Wakefield Street, London WC1N 1 PJ, United Kingdom.

a Present address: Istituto Superior della Sanita, Viale Regina Elena 299, 00161 Rome, Italy.

Copyright (C) 1987 Society for Neuroscience $0270-6474 / 87 / 072203-11 \$ 02.00 / 0$
}

1978; Harris, 1981; Brenneman et al., 1983). As neuronal activity results in membrane depolarization, the effect of chronic depolarization, usually effected by raising the extracellular concentration of $\mathrm{K}^{+}$ions, has been examined in cultured nerve cells, and a prolongation of neuronal survival has indeed been observed in some studies (Scott and Fisher, 1970; Scott, 1971, 1977; Lasher and Zagon, 1972; Phillipson and Sandler, 1975; Chalazonitis and Fishbach, 1980; Currie and Dutton, 1980; Bennett and White, 1981; Thangnipon et al., 1983). It is not yet clear how depolarization affects neuronal survival. However, depolarization also exerts an influence on the development of certain types of nerve cells, and more information is available concerning the possible mechanisms underlying these effects. Thus, it has been reported that elevated $\left[\mathrm{K}^{+}\right\rceil_{\mathrm{e}}$ directs sympathetic neurons towards completing adrenergic differentiation (Walicke et al., 1977; Walicke and Patterson, 1981), leads to selective changes in the expression of transmitter enzymes (Ishida and Deguchi, 1983), and stimulates the growth, as well as the developmental increase in choline acetyltransferase (ChAT) activity, of ciliary neurons (Nishi and Berg, 1981). Increased $\left[\mathrm{K}^{+}\right]_{\mathrm{c}}$ activates voltage-sensitive calcium channels (Blaustein, 1975; Tsien, 1983), and $\mathrm{Ca}^{2+}$ entry has been implicated in these studies in the developmental effects of depolarization.

In the present work, we examined mechanisms by which elevated $\left[\mathrm{K}^{+}\right]_{\mathrm{e}}$ might prolong neuronal survival. In particular, we explored the possibility that calcium may serve as a second messenger in this effect. Cerebellar granule cells were studied, as their fate depends on the presence of elevated $\left[\mathrm{K}^{+}\right]_{\mathrm{e}}$ being included in the serum-containing culture medium (Lasher and Zagon, 1972; Thangnipon et al., 1983).

\section{Materials and Methods}

Cell cultures. Cultures enriched in interneurons (about 95\%) were obtained from dissociated cerebella of 8 -d-old Porton rats as previously described (Thangnipon et al., 1983). Cells were grown in basal Eagle's medium (BME; Gibco) supplemented with $10 \%$ heat-inactivated fetal calf serum (FCS), $2 \mathrm{~mm}$ glutamine, and $100 \mu \mathrm{g} / \mathrm{ml}$ gentamicin on poly( $\mathrm{L}-$ lysine)-coated Falcon dishes $(35 \mathrm{~mm})$. Under the standard conditions, the final concentration of $\mathrm{KCl}$ was $25 \mathrm{~mm}$ (hereafter referred to as $\mathrm{K} 25$ ). Deviations from these conditions are specified in the text. Cytosine arabinoside (Ara-C; $10 \mu \mathrm{M}$ ) was added to all cultures about $19 \mathrm{hr}$ after seeding.

Granule cell-enriched cultures in serum-free, chemically defined medium were grown as described by Kingsbury et al. (1985).

Nerve cell survival. The survival of nerve cells was evaluated by daily examination of cultures using phase-contrast microscopy. In each experiment, at least 4 dishes were examined for each culture condition. When nerve cell death occurred on a massive scale, this usually took place within a $24 \mathrm{hr}$ period, and the last day of overall neuronal survival 

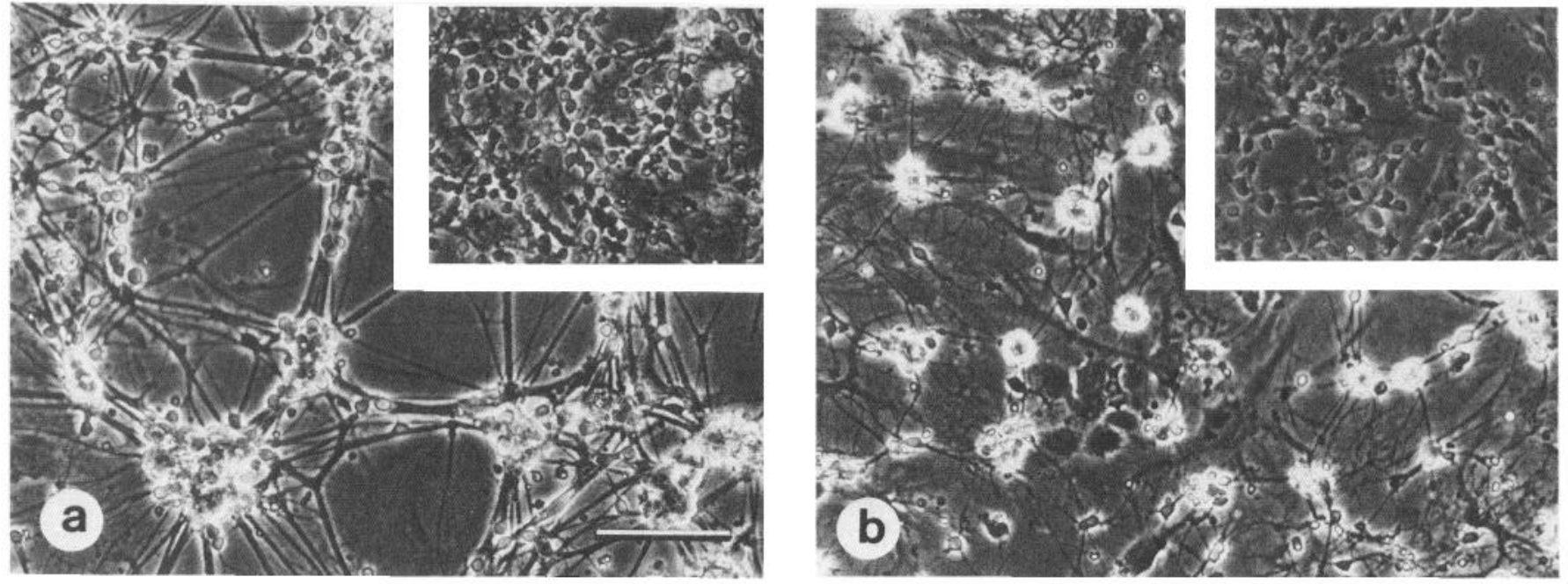

Figure 1. Phase-contrast light micrographs of cerebellar neurons cultured in media containing either $25 \mathrm{mM} \mathrm{K}^{+}(a)$ or 5 mM $\mathrm{K}^{+}(b)$. At $3 \mathrm{DIV}$ (insets), the morphological appearance of the cultures was similar. However, by 7 DIV the majority of nerve cells died in K5, whereas in K25 cultures consisted predominantly of healthy neurons organized into clumps interconnected by thick bundles of fibers. Scale bar, $100 \mu \mathrm{m}$.

could therefore be established with relative accuracy. Nerve cell death was manifested by the appearance of pyknotic and detached cells and by the disintegration of the network of processes (see Fig. 1b, for example).

For quantitative evaluation of cell numbers, DNA was estimated (Burton, 1956) as previously described (Kingsbury et al., 1985). It was assumed that $6 \mu \mathrm{g}$ DNA was equivalent to $1 \times 10^{6}$ cells. We established previously that under standard conditions (K25) the cultures comprise predominantly nerve cells and that the non-neuronal cell number in 5 mM $\mathrm{K}^{+}$-containing medium (K5) was similarly low (Thangnipon et al., 1983). Therefore, DNA values, in conjunction with the survey of cultures by phase-contrast microscopy, gave a good estimate of the effects of different experimental conditions on the survival of nerve cells.

Depolarization-induced release of amino acids. The procedure described previously was followed (Gallo et al., 1982). After removal of the medium, the cultures were washed twice with Krebs-HEPES solution

Table 1. Influence of $\mathrm{K}^{+}$concentration of the medium on the survival of cerebellar nerve cells in culture

\begin{tabular}{|c|c|c|c|c|c|c|}
\hline \multirow[b]{2}{*}{$\mathrm{KCl}(\mathrm{mm})$} & \multicolumn{3}{|c|}{ Cells $/$ dish $\times 10^{-6}$} & \multicolumn{3}{|c|}{ Protcin/DNA ratio } \\
\hline & $2 \mathrm{DIV}$ & 5 DIV & 12 DIV & 2 DIV & 5 DIV & $12 \mathrm{DIV}$ \\
\hline 5 & 1.08 & 0.83 & 0.19 & 8.98 & 16.91 & 21.27 \\
\hline 10 & 0.89 & 0.84 & 0.19 & 9.97 & 12.28 & 25.28 \\
\hline 15 & 0.89 & 0.87 & 0.35 & 9.40 & 11.46 & 20.89 \\
\hline 20 & 0.96 & 0.96 & 0.81 & 9.18 & 13.96 & 16.54 \\
\hline 25 & 0.96 & 1.09 & 0.88 & 7.01 & 13.14 & 17.62 \\
\hline 50 & 0.94 & 0.98 & 0.86 & 9.35 & 14.18 & 17.58 \\
\hline
\end{tabular}

Effect of $\left[\mathrm{K}^{+}\right]$

$$
(d f=5)
$$

$$
F=34.3(p<0.001) \quad F=2.24 \quad(p<0.057)
$$

Effect of culture time

$$
\begin{array}{cll}
(d f=2) & F=172.9(p<0.01) & F=115.9(p<0.0001) \\
\operatorname{SEM}(d f=18) & 0.06 & 1.72
\end{array}
$$

Cells from P8 dissociated rat cerebella were cultured in $35 \mathrm{~mm}$ dishes as described in Materials and Methods ( $10 \mu \mathrm{M}$ Ara-C was added at the end of the first day to block glial proliferation). The data from a representative experiment are the mean of 2 separate estimations, derived from measurements of DNA and protein on pooled groups of 5 dishes. Cell numbers per dish were calculated assuming a DNA content of $6.0 \mu \mathrm{g} / 10^{6}$ cells, while the protein and DNA estimates were in $\mu \mathrm{g} / \mathrm{dish}$ Data were analyzed by analysis of variance with 2 -way classification using SPSS ${ }^{\times}$ on the Amdahl V8 computer at the University of London Computer Centre. When the data on cell numbers were treated as 2 groups with respect to $\mathrm{K}^{+}$concentration (group 1, 5-15 mм K+; group 2, 20-50 $\mathrm{mm} \mathrm{K}^{+}$), a linear contrast showed that the 2 groups were significantly different, $p<0.001$.
$(128 \mathrm{~mm} \mathrm{NaCl}, 5 \mathrm{~mm} \mathrm{KCl}, 2.7 \mathrm{~mm} \mathrm{CaCl}, 1.2 \mathrm{~mm} \mathrm{MgSO}, 1 \mathrm{~mm}$ $\mathrm{Na}_{2} \mathrm{HPO}_{4}, 16 \mathrm{~mm}$ glucose, and $20 \mathrm{~mm}$ HEPES, pH 7.4) and incubated for $10 \mathrm{~min}$ in $1.5 \mathrm{ml}$ of the same medium before the addition of $\mathrm{D}^{3}{ }^{3} \mathrm{H}$ aspartate $(1 \mu \mathrm{Ci} / \mathrm{ml}$; specific activity, $20 \mathrm{Ci} / \mathrm{mmol})$. After $10 \mathrm{~min}$ the medium was removed, and the dishes, transferred to a rotating warm $\left(37^{\circ} \mathrm{C}\right)$ plate, were washed 3 times with $2 \mathrm{ml}$ of the amino acid-free medium. For the release studies, the cultures were then subjected to 5 min washes with $1 \mathrm{ml}$ medium. Depolarizing medium $(100 \mu \mathrm{g}$ veratrine/ $\mathrm{ml}$ ) was applied after the fourth wash for $5 \mathrm{~min}$ and 2 further $5 \mathrm{~min}$ washes with the Krebs medium were also collected. The release fractions were acidified with $5 \mu \mathrm{l}$ concentrated $\mathrm{HCl}$ and kept on ice. $\mathrm{D}^{-}{ }^{3} \mathrm{H}$-aspartate was measured in all the "release" fractions, while endogenous glutamate was only estimated in the fractions immediately before, during, and after the stimulation. The glutamate content of the cells was also estimated: After removal of the medium, ice-cold $1 \mathrm{ml} 0.8 \mathrm{M} \mathrm{HClO}_{4}$ was added to the dishes for $1 \mathrm{hr}$. Then, the tissue was scraped off and the suspension centrifuged. Amino acids were estimated in the supernatant, while the protein content of the sediment was measured by the method of Lowry et al. (1951), using a Technicon Autoanalyser. Amino acids were separated by ion-exchange chromatography on a Rank-Hilger Chromspec using a programmed gradient elution system of lithium citrate buffers and determined by the $o$-phthalaldehyde reaction for fluorometry (Holton, 1977).

${ }^{45} \mathrm{Ca}^{2+}$ uptake. The procedure of Zurgil and Zisapel (1984) was used with small modifications. After 2 washes with a balanced salt solution (BSS; $116 \mathrm{~mm} \mathrm{NaCl}, 5.5 \mathrm{~mm} \mathrm{KCl}, 0.8 \mathrm{~mm} \mathrm{MgSO}_{4}, 1.8 \mathrm{~mm} \mathrm{CaCl}_{2}, 1$ $\mathrm{mm} \mathrm{NaH} \mathrm{PO}_{4}, 5.5 \mathrm{~mm}$ glucose, and $2.6 \mathrm{~mm} \mathrm{NaHCO}$, at pH 7.4) standard cultures were incubated for $5 \mathrm{~min}$ in humidified air- $\mathrm{CO}_{2}(95 \%$ : $5 \%)$ atmosphere in the presence of $4 \mu \mathrm{Ci} / \mathrm{ml}^{45} \mathrm{Ca}^{2+}(2.2 \mu \mathrm{Ci} / \mu \mathrm{mol})$ either in BSS or in BSS-containing $50 \mathrm{~mm} \mathrm{KCl}$ and $71 \mathrm{~mm} \mathrm{NaCl}$ for $5 \mathrm{~min}$. At the end of this time, the plates were rapidly washed twice with $2 \mathrm{ml}$ of $\mathrm{Ca}^{2+}$-free BSS. Cells were then solubilized in $1 \mathrm{ml} 0.1 \mathrm{M} \mathrm{NaOH}, 0.5$ $\mathrm{ml}$ being used for scintillation counting and $0.25 \mathrm{ml}$ for protein estimation.

Estimation of $\mathrm{N}-\mathrm{CAM}$ (neuronal cell adhesion molecule). Crossed line immunoelectrophoresis was used for estimating the relative specific concentration of N-CAM as previously described by Jørgensen (1981) and Gallo et al. (1985). (Those authors used the name D2 protein instead of N-CAM.)

Protein synthesis rate. This was estimated as described before (Patel et al., 1984). Cultures were incubated in Krebs solution with $5 \mu \mathrm{Ci}$ $\mathrm{U}-{ }^{14} \mathrm{C}$-leucine. Leucine concentration was $1 \mathrm{~mm}$; this ensured that the specific radioactivity in the different cellular compartments and the medium was constant, thus providing valid measures of the amino acid incorporation rates (Dunlop et al., 1977). The ${ }^{14} \mathrm{C}$ content of trichloroacetic acid-precipitated material was estimated over 30-120 min, and the rate was found to be linear during this period.

Chemicals. ${ }^{45} \mathrm{Ca}^{2+}, \mathrm{D}^{-3} \mathrm{H}$-aspartate and $\mathrm{U}-{ }^{14} \mathrm{C}$-leucine were from Amersham International. Nifedipine, TTX, and veratrine were from 


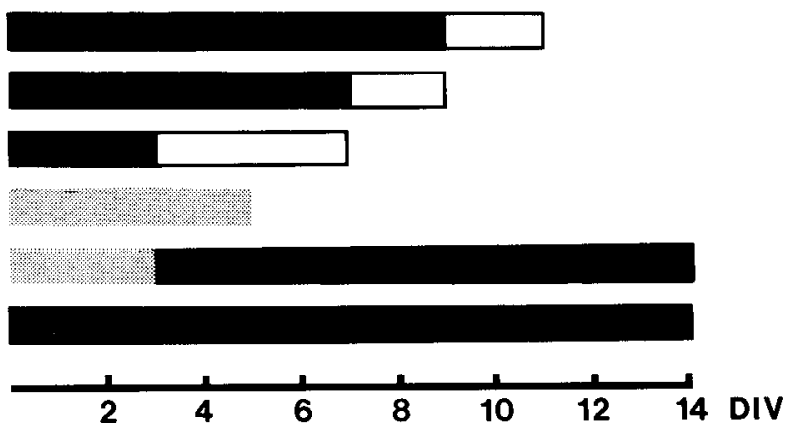

K 25
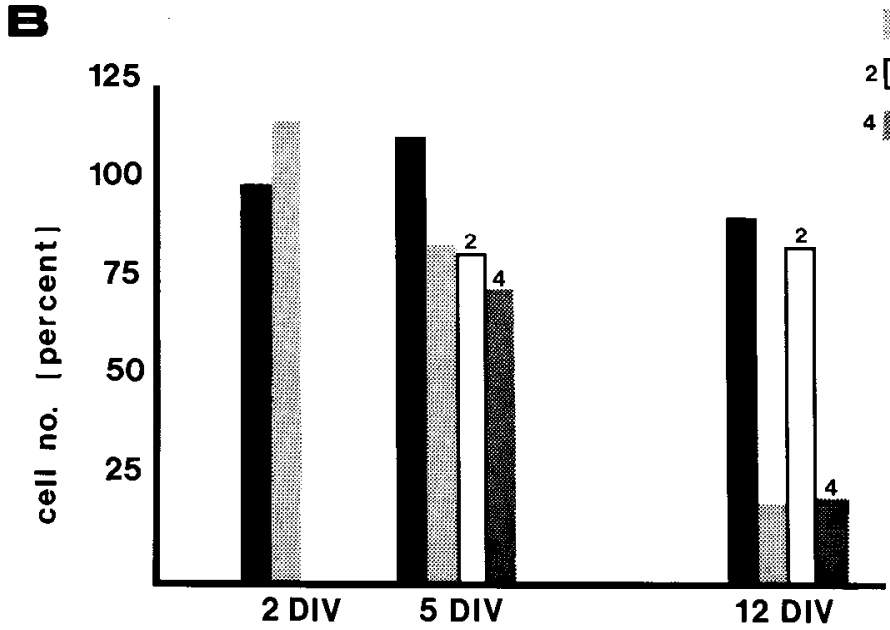

Figure 2. $A$, Nerve cell survival was assessed qualitatively by daily microscopic examination of the cultures for $14 \mathrm{~d}$ as described in Materials and Methods. The results represent mean survivals observed in at least 3 experiments in which the time of massive nerve cell death did not differ by more than $24 \mathrm{hr}$. Nerve cells survived in K5 (stippled bar) for only $5 \mathrm{~d}$ but were well maintained during the experimental period in $\mathrm{K} 25$ (solid bar) or when transferred from K 5 to K 25 at 3 DIV. Shifting the cultures from K25 to K15 (open bar) resulted in neuronal degeneration within a few days. $B$, Results from a representative experiment. Cell number at 2 DIV in standard culture conditions (K25, $0.96 \times 10^{6}$ cells $/$ dish $)$ is taken as the reference value $(100 \%)$. Cell number was determined by DNA measurement, and each value is the mean of 2 estimates on pooled groups of 5 dishes. The bars represent cell numbers in cultures grown in K 25 and K 5 (solid and lightly stippled bars) or shifted from K5 to K25 either at 2 DIV (open bar. 2) or at 4 DIV (heavily stippled bar, 4).
Sigma, xylocaine from Astra Pharmaceuticals, and calmidazolium from Janssen Pharmaceutica. The following substances were generously donated: trifluoperazine (Smith Kline \& French Ltd., Welwyn Garden City, Herts., U.K.); D600 (Knoll AG, D-6700, Ludwigshafen, FRG); BAY K 8644 (Prof. F. Hoffmeister and Dr. B. Garthof, Bayer AG, Wupperstal, FRG); the 2 enantiomers of 202791 (Dr. B. Gähwiler, Sandoz Ltd., Basel) and CGP 28392 (Prof. H. Brunner, CIBA-Geigy AG, Basel).

\section{Results}

\section{Extracellular $K^{+}$concentration and nerve cell survival}

The culture conditions employed in the present study, i.e., FCScontaining medium supplemented with $10 \mu \mathrm{M}$ Ara-C by the end of the first day, selected for the survival and maintenance of cerebellar interneurons, predominantly granule cells (Thangnipon et al., 1983; Kingsbury et al., 1985). When the proportion of non-neuronal cells was kept low, as under these conditions $(<5 \%)$, nerve cells died usually within a week, unless the $\left[\mathrm{K}^{+}\right]_{\mathrm{e}}$ was raised above the physiological level. In contrast to the effect of $\mathrm{K}^{+}$on relatively long-term survival, the initial steps of neuronal differentiation, such as fiber emission, were similar in the K5 and K25 medium (Fig. 1).

Cell survival as a function of the $\left[\mathrm{K}^{+}\right]$in the medium was investigated next. Table 1 shows that, up to $5 \mathrm{~d}$ after seeding, $\left[\mathrm{K}^{+}\right]_{\mathrm{e}}$ in the range of 5-50 $\mathrm{mm}$ had little, if any, influence on cell numbers, as evaluated by DNA estimation. However, by 12 DIV the number of cells was markedly reduced, while the average cell size, assessed by the cellular protein content, increased in the cultures grown in media containing $<20 \mathrm{~mm} \mathrm{~K}^{+}$. Microscopic examination of the cultures showed that significant neuronal survival was only evident in the presence of $\mathrm{K}^{+}$concentrations of $20 \mathrm{~mm}$ or higher. In comparison with the standard conditions (K25), doubling the $\mathrm{K}^{+}$concentration did not modify either the appcarance of the cultures or the number or survival time of the cells.

When cerebellar neurons were grown for the first 2 or $3 \mathrm{~d}$ in the presence of $5 \mathrm{mM} \mathrm{KCl}$ and then shifted to $25 \mathrm{mM} \mathrm{KCl}$, they survived as long as the cells cultured in K25 from the time of seeding (Fig. 2A). Furthermore, the morphological appearance of the "shifted" cultures was similar to that of cultures in K25. The microscopic assessment of overall neuronal survival in the cultures was consistent with the quantitative estimation of cell numbers by measuring DNA contents (compare Fig. 2, $A$ and $B$ ). Figure $2 B$ also shows that the timing of transferring cells from low to high $\mathrm{K}$ media was critical. Rescue of nerve cells could not be effected when the cultures were shifted from K5 to $\mathrm{K} 25$ at $4 \mathrm{~d}$, instead of 2-3 d, after seeding. Moreover, after 3 DIV, continuous exposure to depolarizing concentrations of $\mathrm{K}^{+}$was essential, as transfer from media containing $25 \mathrm{mM} \mathrm{KCl}$ 
Figure 3. Release induced by veratrine $(100 \mu \mathrm{g} / \mathrm{ml})$ of endogenous glutamate (upper panels) and of $\mathrm{D}^{3} \mathrm{H}-\mathrm{H}$ partate (lower panels) from granule cell cultures grown in media containing 25 $\mathrm{mm} \mathrm{K}^{+}(A, \mathrm{~K} 25), 5 \mathrm{~mm} \mathrm{~K}^{+}(B, \mathrm{~K} 5)$, and $25 \mathrm{mM} \mathrm{K}^{+}+10 \mathrm{mM} \mathrm{Mg}^{2+}(C, \mathrm{Mg})$ for 5 DIV. Glutamate release into the medium during a $5 \mathrm{~min}$ incubation period was estimated immediately before and after the addition of veratrine (stippled and closed columns, respectively). Results are the means $\pm \operatorname{SEM}(n=4)$ : $t$ tests indicated no significant differences in either the basal or stimulated release of glutamate from the $\mathrm{K} 25$ and $\mathrm{K} 5$ cultures. The difference in the stimulated release of glutamate between $A$ and $C$ was significant $(p<0.02)$. The data on the fractional release of $\mathrm{D}^{-3} \mathrm{H}$ aspartate are the means of 2 experiments: Each point represents $\mathrm{D}^{3}{ }^{3} \mathrm{H}$-aspartate release in $5 \mathrm{~min}$, and the arrow indicates the time at which the cells were exposed to veratrine.
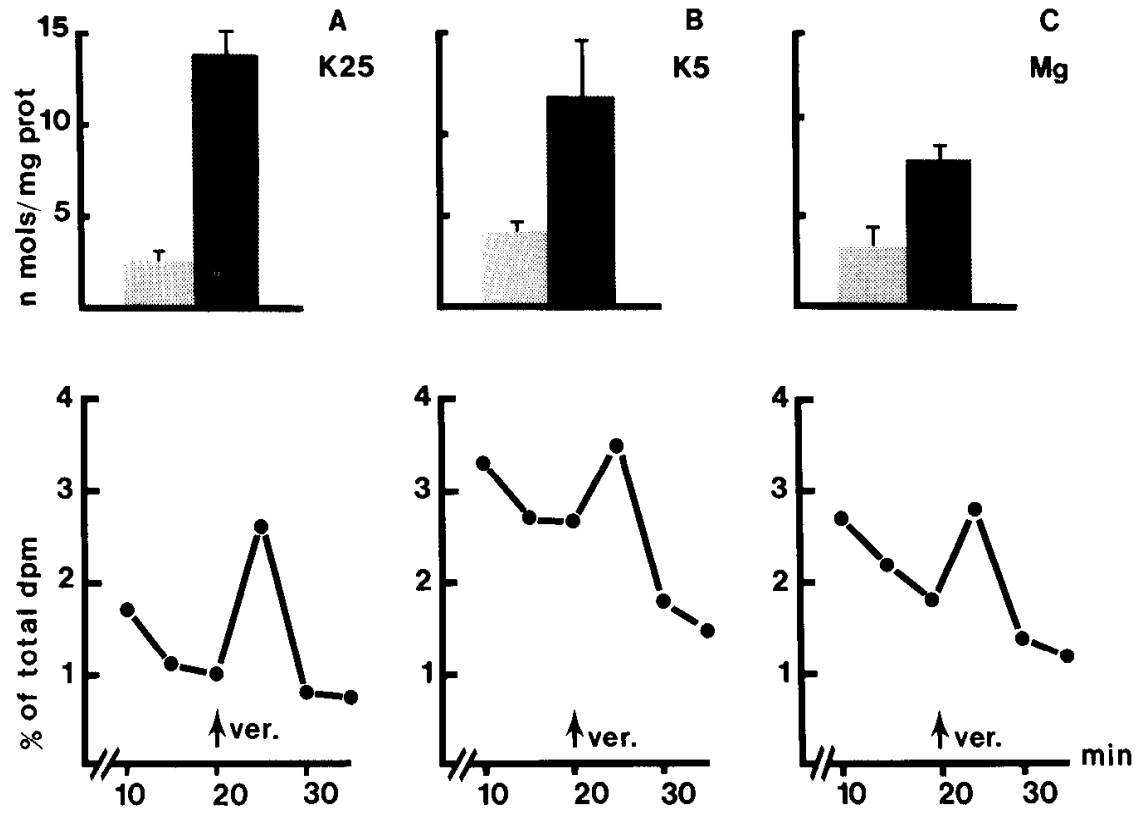

to $15 \mathrm{mM} \mathrm{K}^{+}$any time after 3 DIV resulted in massive nerve cell death within a few days (Fig. $2 A$ ).

\section{Maturation of nerve cells in the presence of $\mathrm{K}^{+}$at physiological or depolarizing concentrations}

The results described above indicated that the dependence of nerve cells on elevated $\left[\mathrm{K}^{+}\right]_{\mathrm{e}}$ is established after a few days in culture. Depolarizing conditions may exert an influence on the maturation of nerve cells during the initial culture period, which may be relevant for the survival of the cells. As an index of neuronal differentiation, we examined the stimulus-coupled release of glutamate (the transmitter of granule cells), which under the standard conditions (K25) becomes manifest only after 4$5 \mathrm{~d}$ in culture (Gallo et al., 1982). At 5 DIV, veratrine-induced release of endogenous glutamate and prcloadcd $\mathrm{D}^{-}{ }^{3} \mathrm{H}$-aspartate was similar in the K5 and the K25 cultures (Fig. 3, Table 2).

We also estimated N-CAM (previously designated as D2 protein), which is implicated in cell-cell interaction and the complex processes of histogenesis in nervous tissues (for review, see Edelman, 1984). It has been previously documented that N-CAM shows both quantitative and qualitative changes during the development of cerebellar cultures grown under the standard conditions (Jørgensen, 1981; Meier et al., 1984). Table 3 shows that there was no significant difference between the cells grown in media containing elevated or normal $\mathrm{K}^{+}$levels either in the increase in the concentration of N-CAM during the culture pe- riod or in the proportion of the protein in the less sialylated "adult" form. It would appear that initial growth was also similar in the K5 and K25 cultures (Table 2). The increase in the cellular protein content during the first $5 \mathrm{~d}$ and the rate of protein synthesis at 4 DIV were comparable, although cell numbers were already somewhat reduced in the $\mathrm{K} 5$ cultures at $5 \mathrm{DIV}$.

\section{Conditions that may replace elevated $\left[\mathrm{K}^{+}\right]_{e}$ or counteract its effect on neuronal survival}

The effect of elevated $\left[\mathrm{K}^{+}\right]_{\mathrm{e}}$ on neuronal survival was reproduced by adding $20 \mathrm{~mm} \mathrm{Rb^{+ }}$ to a $\mathrm{K} 5$ medium. Under these conditions, both the appearance of the cultures, monitored daily for a fortnight by phase-contrast microscopy, and the overall survival of cells were similar to those observed in K25 medium (not shown). However, the results obtained with other depolarizing agents, such as veratrine and veratridine, were equivocal, because of their high toxicity to cerebellar neurons.

Pyruvate has recently been identified as a factor essential for the survival of different types of nerve cells in culture (Selak et al., 1985). As high $\left[\mathrm{K}^{+}\right]_{\mathrm{c}}$ is expected to increase the rate of aerobic breakdown of glucose, the effect of supplementation of the $\mathrm{K} 5$ medium with $1 \mathrm{~mm}$ pyruvate was tested; however, it was found to be ineffective in preventing early cerebellar neuronal degeneration.

In the next series of experiments, we examined whether the effect of depolarizing concentrations of extracellular $\mathrm{K}^{+}$ions on

Table 2. Initial maturation of cerebellar nerve cells cultured in the presence of 5 or $25 \mathrm{~mm} \mathrm{~K}$

\begin{tabular}{|c|c|c|c|c|c|c|c|}
\hline \multirow{3}{*}{$\begin{array}{l}{\left[\mathrm{K}^{+}\right]} \\
(\mathrm{mM})\end{array}$} & & & & & \multirow{3}{*}{$\begin{array}{l}\text { Protein synthesis } \\
\text { (rate) }(\mathrm{nmol} / \mathrm{mg} / \mathrm{hr} \text { ) } \\
4 \mathrm{DIV}\end{array}$} & \multicolumn{2}{|c|}{$\begin{array}{l}\text { Glutamate release }(\mathrm{nmol} / \mathrm{mg} / \\
\text { min) }\end{array}$} \\
\hline & \multicolumn{2}{|c|}{ Cell no./dish $\left(\times 10^{-6}\right)$} & \multicolumn{2}{|l|}{ Protein/DNA } & & Basal & Evoked \\
\hline & 2 DIV & 5 DIV & $2 \mathrm{DIV}$ & 5 DIV & & \multicolumn{2}{|c|}{5 DIV } \\
\hline 5 & $1.08 \pm 0.008$ & $0.77 \pm 0.038$ & $9.72 \pm 0.463$ & $15.9 \pm 1.43$ & $5.45 \pm 0.468$ & $3.27 \pm 0.532$ & $11.5 \pm 3.09$ \\
\hline 25 & $1.07 \pm 0.067$ & $1.07 \pm 0.032$ & $8.86 \pm 1.092$ & $14.4 \pm 0.80$ & $4.96 \pm 0.468$ & $2.55 \pm 0.175$ & $13.7 \pm 1.66$ \\
\hline$p$ & NS & $<0.002$ & NS & NS & NS & NS & NS \\
\hline
\end{tabular}

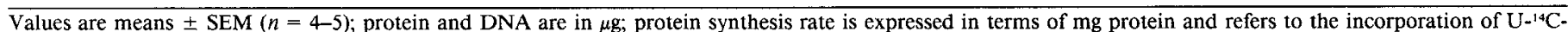
leucine $(5 \mu \mathrm{Ci} / \mathrm{dish}, 1 \mathrm{mM})$ into trichloroacetic acid-precipitated material; glutamate release was induced with $100 \mu \mathrm{g} / \mathrm{ml} \mathrm{veratrine}$. 
Table 3. Effect of $\mathrm{K}^{+}$concentration of the medium on the development of $\mathrm{N}-\mathrm{CAM}$ in cerebellar granule cell cultures

\begin{tabular}{|c|c|c|c|}
\hline \multirow[b]{2}{*}{$\begin{array}{l}\mathrm{KCl} \text { concentration } \\
(\mathrm{mM})\end{array}$} & \multirow[b]{2}{*}{ DIV } & \multicolumn{2}{|l|}{ N-CAM } \\
\hline & & $\begin{array}{l}\text { Relative } \\
\text { spccific } \\
\text { concentration }^{a}\end{array}$ & $\begin{array}{l}\text { "Adult" form } \\
\text { as fraction of } \\
\text { total }\end{array}$ \\
\hline 5 & 3 & $0.76 \pm 0.047$ & $0.48 \pm 0.0268$ \\
\hline 5 & 7 & $1.17 \pm 0.152$ & $0.64 \pm 0.0247$ \\
\hline 25 & 3 & $0.76 \pm 0.078$ & $0.52 \pm 0.361$ \\
\hline 25 & 7 & $1.44 \pm 0.025$ & $0.70 \pm 0.053$ \\
\hline \multicolumn{2}{|c|}{ Effect of $\mathrm{K}^{+}$concentration $(d f=1)$} & $F=3.8$ & $F=3.6$ \\
\hline \multicolumn{2}{|c|}{ Effect of cultivation time $(d f=1)$} & $F=62.6$ & $F=31.7$ \\
\hline \multicolumn{2}{|l|}{ Interaction $(d f=1)$} & $F=3.7$ & $F=0.1$ \\
\hline \multicolumn{2}{|l|}{$\operatorname{SEM}(d f=8)$} & 0.07 & 0.03 \\
\hline
\end{tabular}

Granule cells were grown in culture media containing $\mathrm{KCl}$ at the concentrations indicated. Mean values and individual SEM's are given $(n=3)$. The data were analyzed by 2 -way ANOVA. The effect of $\mathrm{K}^{+}$concentration was not significant, while that of cultivation time was ( $p<0.001$, for both estimates).

a The specific concentration of N-CAM was calculated relative to the concentration in the adult rat forebrain (normalized with respect to protein concentration).

neuronal survival can be counteracted by agents that block the bioelectric activity of the cells. Culturing cells in the presence of TTX, a specific inhibitor of the voltage-sensitive $\mathrm{Na}^{+}$channels, at concentrations that would completely block the veratrine-induced release of glutamate in "mature" cerebellar cultures, did not prevent elevated $\left[\mathrm{K}^{+}\right]_{\mathrm{e}}$ from exerting a positive effect on neuronal survival (Table 4). Furthermore, the local anesthetic xylocaine, at concentrations known to inhibit electrical activity in cultured cells (e.g., Crain et al., 1968), also failed to counteract the effect of elevated $\left[\mathrm{K}^{+}\right]_{\mathrm{e}}$ on neuronal survival (Table 4). It is important to note that the presence of TTX or xylocaine in the K25 medium throughout the culture period did not prevent the development of the stimulus-coupled release of glutamate, which, in 10 DIV cultures, was only modestly lower than that observed in the controls (Table 4).

\section{Effect of calcium}

It has been well documented that elevation of $\left[\mathrm{K}^{+}\right]_{\mathrm{e}}$ leads to an increase of ${ }^{45} \mathrm{Ca}^{2+}$ uptake in various preparations of nervous tissues (e.g., Blaustein, 1975). Figure 4 shows that this also applies to cultured cerebellar interneurons. When grown under the standard conditions and incubated in $5 \mathrm{mM} \mathrm{K}^{+}$-containing medium, those cells took up ${ }^{45} \mathrm{Ca}^{2+}$, the rate of accumulation

Table 4. Effect of xylocaine and TTX on granule cells in culture

\begin{tabular}{llllll} 
Culture & Cells/dish $\times$ & $\begin{array}{l}\text { Protein/ } \\
\text { Conditions }\end{array}$ & $10^{-6}$ & \multicolumn{2}{l}{$\begin{array}{l}\text { Glutamate release } \\
\text { (nmol/mg protein } / 5 \mathrm{~min})\end{array}$} \\
\hline Control & $0.82,0.88$ & $20.1,21.7$ & $1.09,2.31$ & $17.3,19.9$ \\
TTX & $0.69,0.81$ & $19.5,18.6$ & $1.0,1.65$ & $11.4,13.6$ \\
Xylocaine & $0.59,0.64$ & $22.4,21.9$ & $1.84,2.36$ & $14.9,23.5$
\end{tabular}

Cells were cultured in medium containing $25 \mathrm{~mm} \mathrm{~K}^{+}$in the presence or absence of $50 \mu \mathrm{g} / \mathrm{ml}$ xylocaine or $1 \mu \mathrm{M}$ TTX for $10 \mathrm{~d}$. Glutamate release was estimated in cultures incubated in Krebs-HEPES medium as described in Materials and Methods. Means of 2 estimations from 2 independent experiments are shown (cells from 5 dishes were pooled for DNA and protein estimation).

Statistical analysis (analysis of variance and covariance with repeated measure for glutamate release) did not indicate significant differences between the groups.

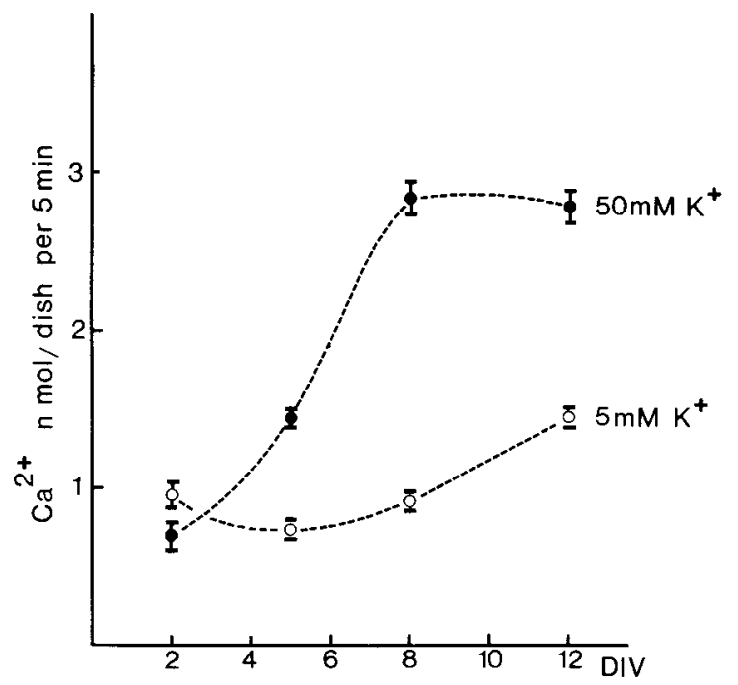

Figure 4. Development of depolarization-induced uptake of $\mathrm{Ca}^{2+}$ in granule cells in culture. Cells were grown under standard conditions (K25). After the indicated times, ${ }^{45} \mathrm{Ca}^{2+}$ uptake was determined in cells incubated in a balanced salt solution as described in Materials and Methods. Results are the means $\pm \operatorname{SEM}(n=5)$.

being only slightly increased with the age of the culture. On the other hand, culture time had a very marked effect on the rate of ${ }^{45} \mathrm{Ca}^{2+}$ uptake induced by depolarizing the cells with $50 \mathrm{~mm}$ $\mathrm{KCl}$. Voltage-sensitive ${ }^{45} \mathrm{Ca}^{2+}$ uptake was not detectable at 2 DIV but was evident at $5 \mathrm{DIV}$, and the rate further increased to a plateau at 8-12 DIV. It appeared, therefore, that there was a parallel between the onset of depolarization-induced ${ }^{45} \mathrm{Ca}^{2+}$ influx and the dependence of cerebellar neurons on elevated $\left[\mathrm{K}^{+}\right]_{\mathrm{e}}$ for survival.

In order to assess whether the effect of cultivation in elevated $\left[\mathrm{K}^{+}\right]_{\mathrm{e}}$ on neuronal survival could, in fact, be related to an increased influx of $\mathrm{Ca}^{2+}$, we tested the effect of conditions expected to interfere with $\mathrm{Ca}^{2+}$ uptake, including addition of either EGTA or $\mathrm{Ca}^{2+}$ antagonists ( $10 \mathrm{mM} \mathrm{Mg}^{2+}$ or $10 \mu \mathrm{M}$ D600) to the $\mathrm{K} 25$ medium. The initial development of the cultures was not affected by these agents, and compared with controls, the mor-

Table 5. Effect of $\mathrm{Ca}^{2+}$ antagonists on neuronal survival

\begin{tabular}{|c|c|c|c|c|}
\hline \multirow[b]{2}{*}{ Culture conditions } & \multicolumn{2}{|c|}{ Cells $/$ dish $\times 10^{-6}$} & \multicolumn{2}{|c|}{$\begin{array}{l}\text { Protein/DNA } \\
\text { ratio }\end{array}$} \\
\hline & $2 \mathrm{DIV}$ & $4 \mathrm{DIV}$ & $\overline{2 \mathrm{DIV}}$ & $4 \mathrm{DIV}$ \\
\hline K25 & 1.125 & 1.01 & 13.65 & 14.65 \\
\hline K5 & 1.00 & 0.795 & 10.17 & 12.81 \\
\hline $\mathrm{K} 25+\mathrm{Mg}^{2+}$ & 0.943 & 0.760 & 10.97 & 14.34 \\
\hline K25 + EGTA & 0.865 & 0.913 & 10.48 & 13.48 \\
\hline $\mathrm{K} 25+\mathrm{D} 600$ & 1.17 & 0.783 & 10.59 & 14.61 \\
\hline Effect of medium $(d f=4)$ & \multicolumn{2}{|c|}{$\begin{array}{l}F=4.983 \\
(p<0.01)\end{array}$} & \multicolumn{2}{|c|}{$\begin{array}{l}F=3.35 \\
(p<0.05)\end{array}$} \\
\hline Effect of time $(d f=1)$ & \multicolumn{2}{|c|}{$\begin{array}{l}F=38.29 \\
(p<0.0001)\end{array}$} & \multicolumn{2}{|c|}{$\begin{array}{l}F=32.9 \\
(p<0.0001)\end{array}$} \\
\hline $\operatorname{SEM}(d f=30)$ & \multicolumn{2}{|l|}{0.054} & \multicolumn{2}{|l|}{0.773} \\
\hline
\end{tabular}

Variables in the culture medium are indicated; K5 and K25 refer to the $\mathrm{K}^{+}$ concentrations ( 5 and $25 \mathrm{~mm}$, respectively); $\mathrm{Mg}^{2+}, 10 \mathrm{~mm}$ (final concentration); EGTA, $1.6 \mathrm{~mm}$; and D600, $10 \mu \mathrm{m}$. Values are the mean of 4 estimates; statistical analysis was by ANOVA 2-way classification. By 6-8 DIV, nerve cell degeneration was extensive in all the cultures except K25 (see Fig. 5). 

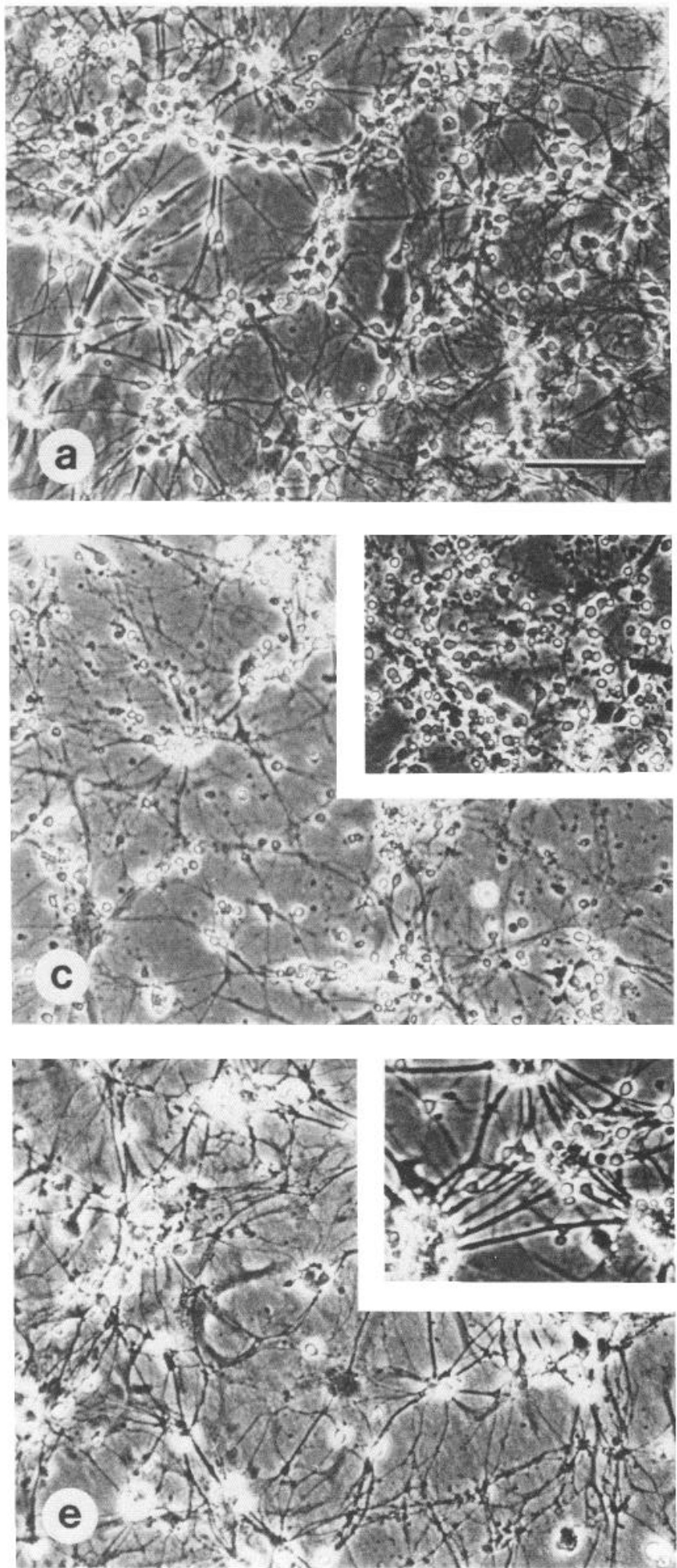
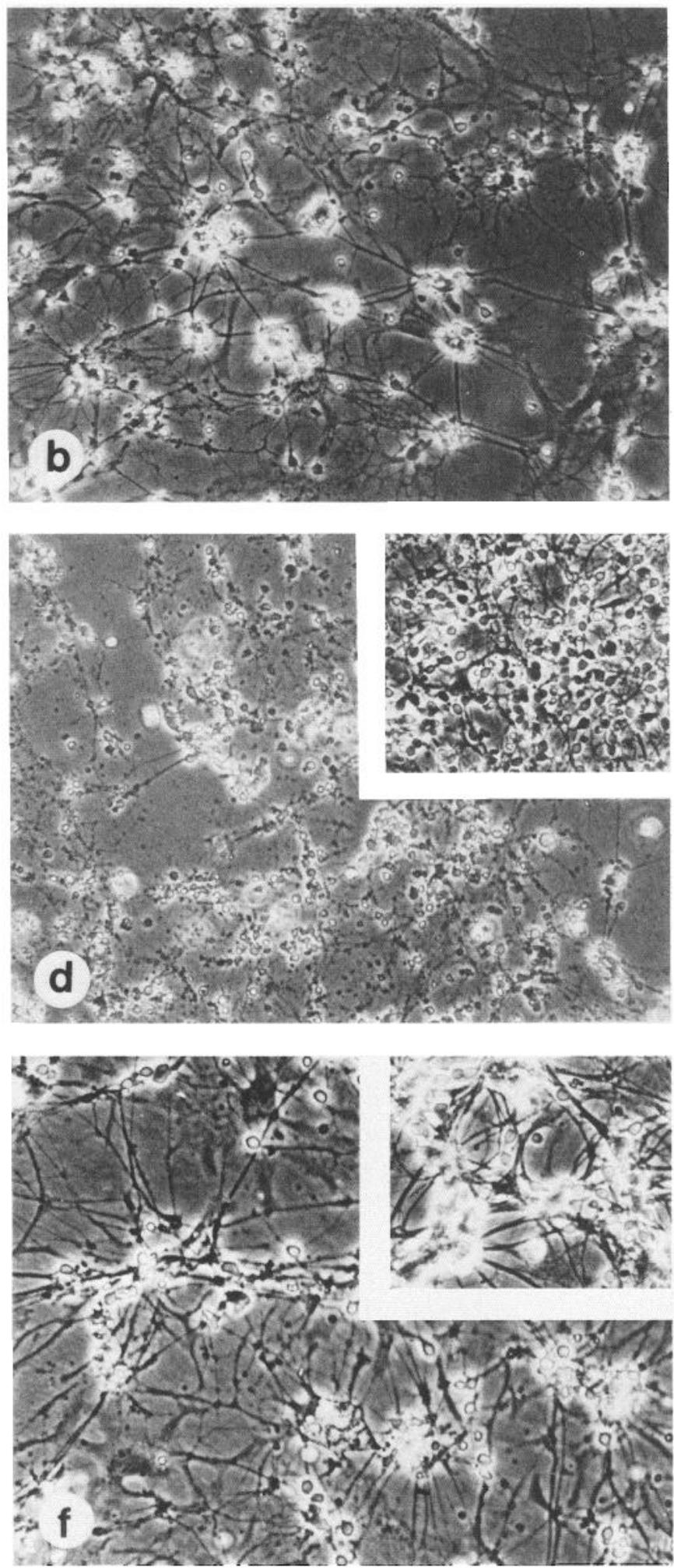

Figure 5. Effect of $\mathrm{Ca}^{2+}$ antagonists on granule cells grown in $\mathrm{K} 25$ medium for 8 DIV. $a$, Standard conditions $(\mathrm{K} 25)$; $b$, 5 mM $\mathrm{K}^{+}$-containing medium; $c$, $\mathrm{K} 25$ containing $10 \mathrm{mM} \mathrm{Mg}^{2+} ; d$, K25 + $10 \mu \mathrm{M} \mathrm{D} 600 ; e, \mathrm{~K} 25+1 \times 10^{-7} \mathrm{M}$ nifedipine; $f, \mathrm{~K} 25+1 \times 10^{-7} \mathrm{M}(-)$-(R)-202 791 . Cultures received the indicated supplements either a few hours after seeding ( $c$ and $d$ ) or at 2 DIV ( $e$ and $f)$. Insets: $c$ and $d$, Respective cultures at 3 DIV; $e$ and $f$, the $\mathrm{Ca}^{2+}$ antagonists at $1 \times 10^{-8} \mathrm{M}$ did not interfere with granule cell survival. Scale bar, $100 \mu \mathrm{m}$.

phological appearance of the cultures was similar at 3 DIV (Fig. $5, c$ and $d$, insets) and cell numbers were only slightly reduced at 4 DIV (Table 5). Furthermore, stimulus-coupled transmitter release also developed, although at 5 DIV veratrine-induced release of glutamate from the cells grown in the high- $\mathrm{Mg}^{2+} \mathrm{K} 25$ medium was significantly lower than in the reference cultures (Fig. 3C). However, in the presence of EGTA, D600, or elevated $\mathrm{Mg}^{2+}$, the majority of the nerve cells degenerated in the $\mathrm{K} 25$ 
medium at about the same age in vitro as in sister cultures grown in $\mathrm{K} 5$, and Figure 5 shows that by 8 DIV virtually all the nerve cells had died.

Apart from influencing $\mathrm{Ca}^{2+}$ entry, the $\mathrm{Ca}^{2+}$ effectors tested may have had additional effects on neuronal metabolism. We observed recently that, in contrast to many neuronal preparations (Miller and Freedman, 1984), dihydropyridine (DHP) $\mathrm{Ca}^{2+}$ effectors are potent agents influencing $\mathrm{Ca}^{2+}$ influx in cultured granule cells (Kingsbury et al., 1986). DHP Ca ${ }^{2+}$ antagonists were therefore tested in the K25 medium. The effect of nifedipine or (-)-(R)-202 791 at $1 \times 10^{-7} \mathrm{M}$ (the lowest effective concentration) was similar to that of the other $\mathrm{Ca}^{2+}$ effectors described above: They had no apparent effect on the initial survival or development of the nerve cells, but after 5-7 d the cells died abruptly, as in the $5 \mathrm{~mm} \mathrm{~K}^{+}$-containing cultures (Fig. $5, b, e, f)$.

Granule cell-enriched cultures can also be grown in a serumfree medium, and under these conditions the fate of the nerve cells does not depend on the presence of depolarizing concentrations of $\mathrm{K}^{+}$(Kingsbury et al., 1985). In serum-free cultures, addition of the $\mathrm{Ca}^{2+}$ antagonist $(-)-(\mathrm{R})-202791\left(1 \times 10^{-7} \mathrm{M}\right)$ did not interfere with the relatively long-term survival of the granule cells.

It would appear, therefore, that $\mathrm{Ca}^{2+}$ antagonists are not toxic to granule cells and that depolarization-induced $\mathrm{Ca}^{2+}$ entry may be responsible for the prolongation of granule cell survival. This hypothesis could be tested by stimulating $\mathrm{Ca}^{2+}$ influx by means other than high $\left[\mathrm{K}^{+}\right]_{\mathrm{e}}$. The effect of the $\mathrm{Ca}^{2+}$ ionophore $\mathrm{A} 23178$ was therefore tested, but this substance was toxic to the cultured cerebellar granule cells. However, DHP $\mathrm{Ca}^{2+}$ agonists at low concentrations stimulate ${ }^{49} \mathrm{Ca}^{3+}$ uptake in to the cultured granule cells (Kingsbury et al., 1986). These agents do not seem to affect ${ }^{45} \mathrm{Ca}^{2+}$ entry in cells incubated in the presence of physiological concentrations of $\mathrm{K}^{+}(5 \mathrm{~mm})$, but they cause a marked stimulation when the cells are even slightly depolarized with $15 \mathrm{~mm}$ $\mathrm{K}^{+}$. Since at this concentration $\mathrm{K}^{+}$had only a slight effect on granule cell survival (Table 1), DHPs were tested under these conditions. The degeneration of granule cells in the $15 \mathrm{~mm} \mathrm{~K} \mathrm{~K}^{+}$ growth medium (Fig. $6 b$ ) was prevented by low concentrations of (+)-(S)-202 791 (Fig. 6,c,d) or BAY K 8644 (Fig. 6,e,f). The appearance of these cultures was comparable to that observed in the high-K+ $\mathrm{K}^{+}$reference cultures (Fig. $6 a$ ). The effect of CGP $28392\left(5-10 \times 10^{-7} \mathrm{M}\right)$ was similar to that of the other $\mathrm{Ca}^{2+}$ agonist DHPs tested, but neuronal survival beyond $10 \mathrm{DIV}$ was apparently less consistent. BAY K 8644 was the most potent of the substances studied; the lowest effective concentration was $10 \mathrm{~nm}$; in contrast, that for (+)-(S)-202 791 was $50 \mathrm{~nm}$. The effect of DHPs on cell survival was also assessed by DNA estimation. At $8 \mathrm{DIV}$, cell numbers, as a percentage of those in K25 cultures $\left(1.16+0.023 \times 10^{6}, n=3\right)$, were 44 and $108 \%$ in the presence of the antagonist and the agonist enantiomers of $202791\left(1 \times 10^{-7}\right.$ and $\left.5 \times 10^{-8} \mathrm{M}\right)$ in K25 and K15 media, respectively.

The effect of $\mathrm{Ca}^{2+}$ may have been mediated through reactions involving calmodulin. Therefore, we examined the influence of trifluoperazine and calmidazolium, which are relatively selective calmodulin blockers. At $1 \mu \mathrm{M}$ these compounds interfered with the survival of the nerve cells (not shown), their effects on the cultures being comparable with those described above for EGTA and the $\mathrm{Ca}^{2+}$ antagonists: Initially, nerve cells survived and differentiated as in the reference cultures, but they died at about the same time as in the $5 \mathrm{~mm} \mathrm{~K}^{+}$medium-after approximately $5 \mathrm{DIV}$.

\section{Discussion}

Increased $\left[\mathrm{K}^{+}\right]_{\mathrm{e}}$ can prolong the survival of some nerve cell types (Scott, 1971, 1977; Lasher and Zagon, 1972; Phillipson and Sandler, 1975; Chalazonitis and Fishbach, 1980; Bennett and White, 1981) and influence neuronal development (Walicke et al., 1977; Nishi and Berg, 1981; Ishida and Deguchi, 1983). Here, we studied the effect of $\left[\mathrm{K}^{+}\right]_{e}$ in a culture containing predominantly a single class of neurons, the cerebellar granule cells, and very few non-neuronal cells (e.g., Thangnipon et al., 1983; Kingsbury et al., 1985); this simplified the experimental situation by limiting the influence of factors derived from glial cells or released from other types of nerve cells. The results confirmed the observations of Lasher and Zagon (1972), who used cultures of less uniform composition and showed that granule cells die when cultured in a medium containing physiological levels of $\mathrm{K}^{+}$within the first week (usually within $5 \mathrm{~d}$ ) but survive longer when $\left[\mathrm{K}^{+}\right]_{\mathrm{e}}$ is elevated. Differences with the findings of Lasher and Zagon (1972) were presumably due to the different culture conditions: In our K5 cultures, granule cell survival was shorter and the cells, although from P8 rats, required the continuous presence of elevated $\left[\mathrm{K}^{+}\right]_{c}$; in contrast, the mixed cultures of Lasher and Zagon (1972) did not require high $\mathrm{K}^{+}$during the first 2 weeks, when cells were derived from $\mathrm{P} 10$ rather than P2 animals.

As the survival of nerve cells in K25 was about 3 weeks, our studies were usually confined to a culture period of $14 \mathrm{~d}$. During the first 2-3 d after plating, exposure to elevated $\left[\mathrm{K}^{+}\right]_{\mathrm{e}}$ was unnecessary for the survival of the nerve cells. When cultures were grown in $\mathrm{K} 5$ for $3 \mathrm{~d}$ and then shifted to $\mathrm{K} 25$, nerve cells survived as well as those maintained in K25 from the time of plating. On the other hand, after 3 DIV the continuous presence of elevated $\left[\mathrm{K}^{+}\right]_{\mathrm{c}}$ was necessary to secure nerve cell survival.

It would appear that many features characteristic of the neuronal phenotype-such as the voltage-sensitive $\mathrm{Na}^{+}$and $\mathrm{Ca}^{+}$ channels (Beale et al., 1980, and the present work, respectively) and stimulus-coupled transmitter release (Gallo et al., 1982)are not detectable in granule cells during the first few days in culture, when the requirement for depolarization is not yet evident. A large proportion of the nerve cells in the plated cell suspension are immature, external granule cells, whose differentiation is prematurely induced in culture. In vivo the differentiation of the postmitotic granule cells takes some time, including a few days of migration to their final destination in the internal granular layer, where they first receive a synaptic input from the mossy fibers. In culture, the development of granule cells was more or less similar in the presence and the absence of elevated $\left[\mathrm{K}^{+}\right]_{\mathrm{e}}$ within the first few days after the initial period, when they did not express a requirement for depolarization. In addition to the morphological appearance, this was also true for specific biochemical neuronal characteristics. Thus, stimuluscoupled glutamate release, which is virtually undetectable at 2 DIV, was similarly well expressed in K5 and K25 cultures at 5 DIV. Furthermore, N-CAM, the level of which is very low in cultures immediately after plating (Meier et al., 1984), showed similar developmental changes in accretion and molecular form under both conditions. These observations indicate, therefore, that elevated $\left[\mathrm{K}^{+}\right]_{\mathrm{e}}$ does not have a marked effect on the initial differentiation of the cerebellar interneurons. Furthermore, the 

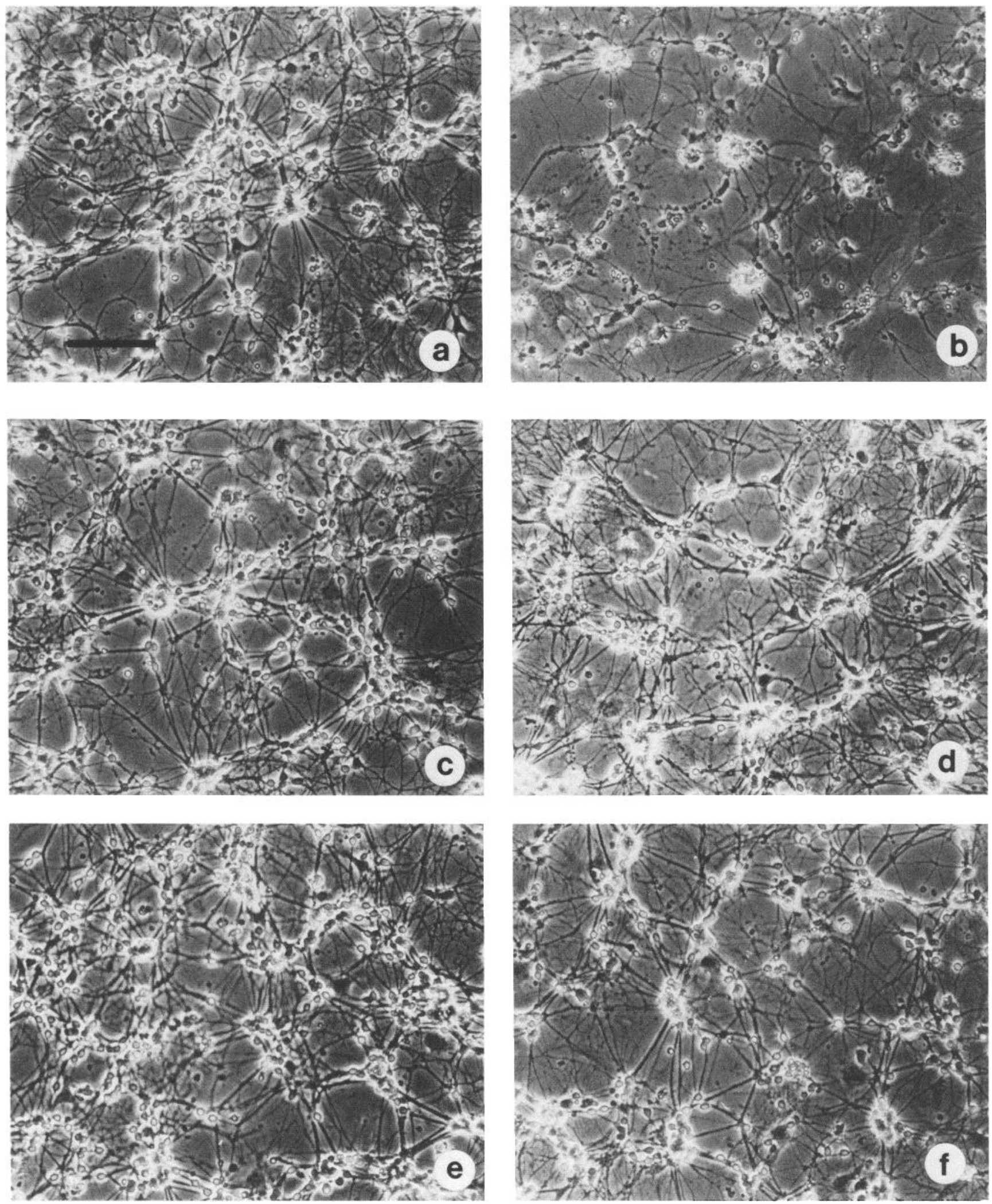

Figure 6. Dihydropyridine $\mathrm{Ca}^{2+}$ agonists promote the survival of granule cells. Cultures grown for $8 \mathrm{DIV}$ in media containing $\mathrm{K}^{+}$at a concentration of $25 \mathrm{~mm}(a)$ or $15 \mathrm{mM}(b-f)$ for $8 \mathrm{DIV}$. Ca $a^{2+}$ agonists were added at $2 \mathrm{DIV}$ : (+)-(S)-202 791 at a concentration of $1 \times 10^{-6} \mathrm{M}(c)$ or $5 \times 10^{-8} \mathrm{M}$ $(d)$ and BAY K 8644 at $1 \times 10^{-7} \mathrm{M}(e)$ or $1 \times 10^{-8} \mathrm{M}(f)$. Scale bar, $100 \mu \mathrm{m}$. 
findings are consistent with the view that granule cells become dependent on elevated $\left[\mathrm{K}^{+}\right]_{\mathrm{e}}$ in parallel with the expression of their differentiated characteristics and that high $\left[\mathrm{K}^{+}\right]_{\mathrm{e}}$ may mimic influences mediated in vivo by the synaptic input they receive at this developmental stage.

It follows from this hypothesis that high $\left[\mathrm{K}^{+}\right]_{\mathrm{e}}$ may induce intracellular events that are normally elicited by the bioelectric activity of the cells and/or by the depolarization of neurons. There is evidence that neuronal activity is necessary for the survival of certain populations of nerve cells (Harris, 1981). We observed, however, that the inhibition of bioelectric activity by means of TTX or xylocaine had no significant effect on the survival of granule cells in culture (Table 4). It was also noted that the differentiation of the cells proceeded under these conditions, since stimulus-coupled transmitter release was immediately manifested after washing out TTX or xylocaine from cultures grown in the presence of these substances for the first $10 \mathrm{~d}$ in vitro. These findings are consistent with the observation of Crain et al. (1968) and Model et al. (1971), who showed that the development of complex synaptic networks in cerebral cortex or spinal cord explants does not depend on prior bioelectric activity. However, it would appear that ongoing neuronal activity has an influence on development and that the stage of cell maturation and experimental conditions detcrmine whether such influences are manifested (Changeux and Danchin, 1976; Black, 1978; Nishi and Berg, 1981; Baker et al., 1982; Betz, 1983; Brenneman et al., 1983; Ishida and Deguchi, 1983).

Detailed investigations on the spinal cord have shown that increased $\left[\mathrm{K}^{+}\right]_{\mathrm{e}}$ has a dual effect: relatively small increases facilitate, while higher concentrations, e.g., $\geq 20 \mathrm{~mm}$ (which are needed for the prolongation of granule cell survival), suppress the action potentials evoked by stimulation and slow conduction velocity along the axons (Syková, 1983). These results therefore support the conclusions drawn from our experiments with TTX and xylocaine and indicate that bioelectric activity per se is not the critical factor in the effect of $\left[\mathrm{K}^{+}\right]_{e}$ on the survival of granule cells.

The failure of TTX to influence nerve cell survival in elevated $\left[\mathrm{K}^{+}\right]_{\mathrm{e}}$ also indicated that the effect of $\left[\mathrm{K}^{+}\right]_{\mathrm{e}}$ is not mediated through voltage-sensitive $\mathrm{Na}^{+}$influx. Neither was the influence of increased $\left[\mathrm{K}^{+}\right]_{\mathrm{e}}$ due to an increase in pyruvate production. As elevated $\left[\mathrm{Rb}^{+}\right]_{\mathrm{e}}$ could replace $\mathrm{K}^{+}$in promoting nerve cell survival, the effect is not specific to $\mathrm{K}^{+}$.

Concentrations of extracellular $\mathrm{K}^{+}$that prolong granule cell survival, $\geq 20 \mathrm{~mm}$ (Table 1 ), cause nerve cell depolarization (Chalazonitis and Fishbach, 1980; Nishi and Berg, 1981), which is known to activate voltage-sensitive $\mathrm{Ca}^{2+}$ channels (Blaustein, 1975; Zurgil and Zisapel, 1984). Such channels are detectable in cultured granule cells (Fig. 4), and in other systems $\mathrm{Ca}^{2+}$ antagonists inhibit certain developmental changes induced by elevated $\left[\mathrm{K}^{+}\right]_{\mathrm{e}}$ (Nishi and Berg, 1981; Walicke and Patterson, 1981; Betz, 1983; Ishida and Deguchi, 1983). We therefore examined whether the effect of elevated $\left[\mathrm{K}^{+}\right]_{\mathrm{e}}$ on the survival of cerebellar nerve cells could be mediated through a depolarization-induced increase of $\mathrm{Ca}^{2+}$ influx. Different means of interference with $\mathrm{Ca}^{2+}$ entry prevented the positive effect of increased $\left[\mathrm{K}^{+}\right]_{\mathrm{e}}$ on the survival of nerve cells (Fig. 5, Table 5). In particular, DHP antagonists, which are potent agents in granule cells (Kingsbury et al., 1986), counteracted the effect of elevated $\left[\mathrm{K}^{+}\right]_{\mathrm{e}}$ at concentrations $\left(1 \times 10^{-7} \mathrm{M}\right)$ at which these substances exert specific effects on muscle or clonal neural cell lines (Miller and
Freedman, 1984; Hof et al., 1985; Preuss et al., 1985). It would appear that the different $\mathrm{Ca}^{2+}$ effectors were not cytotoxic at the concentrations used: During the first $5 \mathrm{~d}$, the morphological maturation and growth of the cells, in terms of accretion of cellular proteins, were similar in the presence or absence of these compounds; stimulus-coupled transmitter release did develop in the presence of $\mathrm{Ca}^{2+}$ antagonists, although by $5 \mathrm{DIV}$ the magnitude of the release was somewhat smaller than in controls (Fig. 3). Moreover, the DHP Ca ${ }^{2+}$ antagonist (-)-(R)-202 791 did not interfere with the survival of the nerve cells in serumfree granule cell cultures, in which the cells can be maintained for relatively long periods in the presence of physiological $\left[\mathrm{K}^{+}\right]_{\mathrm{e}}$ (Kingsbury et al., 1985).

Also, the requirement for continuous exposure to elevated $\left[\mathrm{K}^{+}\right]$for the survival of granule cells and the inhibition by $\mathrm{Ca}^{2+}$ antagonists of this effect indicate that voltage-dependent $\mathrm{Ca}^{2+}$ channels are not entirely inactivated during the chronic exposure to elevated $\left[\mathrm{K}^{+}\right]_{\mathrm{c}}$. This is not unusual, as it is known that $\mathrm{Ca}^{2+}$. channel inactivation is an extremely variable phenomenon from one cell type to another (Tsien, 1983).

Furthermore, depolarizing agents other than high $\mathrm{K}^{+}$that can cause increased $\mathrm{Ca}^{2+}$ entry did not show clear effects on granule cell survival. Veratrine at $\geq 10 \mu \mathrm{g} / \mathrm{ml}$ caused early degeneration of these cells cven in the K25 mcdium, whercas at $2 \mu \mathrm{g} /$ $\mathrm{ml}$ it had no effect on the survival of the cells in K5. A 23187 at 4-20 $\mu \mathrm{M}$ was toxic to granule cells, causing extensive cell loss within $24 \mathrm{hr}$. It is known that this agent, in addition to being a $\mathrm{Ca}^{2+}$ ionophore, also markedly alters the fluidity of the cell membrane (Klausner et al., 1979), and this may compromise cell survival. Nevertheless, the agents would merit more detailed studies in terms of the concentration dependence of $\mathrm{Ca}^{2}$ uptake and of cell survival.

The proposal that the effect of elevated $\left[\mathrm{K}^{+}\right]_{\mathrm{e}}$ on neuronal survival is mediated through depolarization-induced $\mathrm{Ca}^{2+}$ entry gains strong support from the observation that agents which stimulated $\mathrm{Ca}^{2+}$ influx via the voltage-sensitive channels could replace potassium. Supplementation of the "nonsurviving" cultures with the DHP Ca ${ }^{2+}$ agonists BAY K 8644 or (+)-(S)-202 791 at low concentrations $\left(1 \times 10^{-8}\right.$ or $\left.5 \times 10^{-8} \mathrm{M}\right)$ prevented neuronal loss, as did elevated $\left[\mathrm{K}^{+}\right]_{\mathrm{e}}$ (Fig. 6). It should be noted that the sensitivity of granule cells to these agents compares favorably with that of aortic rings $\left(\mathrm{EC}_{50}\right.$ for (+)-(S)-202 791, $1.8 \times 10^{-7} \mathrm{M}$ : Hof et al., 1985) or of cardiac muscle $\left(\mathrm{EC}_{50}\right.$ of the inotropic effect of BAY K $8644,5.2 \times 10^{-8}$ M: Rogg et al., 1985).

Further experiments suggested that the effect of the depolarization-induced transmembrane $\mathrm{Ca}^{2+}$ flux may be mediated through reactions involving calmodulin. Calmodulin inhibitors such as trifluoperazine or calmidazolium at $1 \mu \mathrm{M}$ blocked the effect of elevated $\left[\mathrm{K}^{+}\right]_{e}$ on granule cell survival. Inhibition by $10 \mu \mathrm{M}$ TFP of the depolarization-evoked induction of tyrosine hydroxylase in cultured sympathetic neurons has been ascribed previously to an interference with calmodulin-mediated reactions (Hefti et al., 1982). It should be noted that calmodulin inhibitors do not reproduce all the effects of $\mathrm{Ca}^{2+}$ antagonists on cultured cells; for example, $\alpha$-bungarotoxin receptor binding in chick retina cultures is increased by $\mathrm{Ca}^{2+}$ antagonists, but is unaffected by TFP (Betz, 1983). Nevertheless, the specificity of these substances is limited as they also affect processes other than those involving calmodulin. However, the relative specificity of the TFP effect was indicated by the finding that although 
TFP also interfered with evoked glutamate release (not shown), much higher concentration was needed for the inhibition (15 $\mu \mathrm{M})$ than for influencing the survival of the cerebellar interneurons $(1 \mu \mathrm{M})$.

The finding that activation of voltage-sensitive $\mathrm{Ca}^{2+}$ channels is involved in granule cell survival is apparently at variance with observations indicating that long-term increases in $\mathrm{Ca}^{2+}$ entry are often associated with neuronal damage (e.g., Siesjö, 1981). However, the toxic effects are accompanied by a lasting elevation of cytoplasmic $\mathrm{Ca}^{2+}$ activity. The fact that neuronal degeneration did not occur after the stimulation of $\mathrm{Ca}^{2+}$ influx into granule cells by elevated $\left[\mathrm{K}^{+}\right]_{\mathrm{e}}$ or $\mathrm{Ca}^{2+}$ agonists indicates that regulatory mechanisms keep the free intracellular $\mathrm{Ca}^{2+}$ levels within a nontoxic range. If so, $\mathrm{Ca}^{2+}$ entry through the voltagesensitive channels may affect some localized intracellular reaction(s). $\mathrm{K}^{+}$-induced depolarization may mimic the physiological stimulation of granule cells (see above). This is effected by mossy fibers, many of which function with acidic amino acids as their transmitters. Electrophysiological studies have indicated that granule cells possess exitatory amino acid receptors, including the $N$-methyl-D-aspartate receptor subtype (Cull-Candy and Ogden, 1985). It scems that thesc receptors gatc channcls that are permeable not only to monovalent ions, but also to $\mathrm{Ca}^{2+}$ (MacDermott et al., 1986), while depolarization caused by the stimulation of other excitatory amino acid receptors may lead to $\mathrm{Ca}^{2+}$ entry through voltage-sensitive channels. One important consequence of this $\mathrm{Ca}^{2+}$ flux may be the activation of a $\mathrm{Ca}^{2+} /$ calmodulin-dependent protein kinase (type II CaM kinase), which is relatively concentrated in postsynaptic membranes (Miller and Kennedy, 1985). Activation by $\mathrm{Ca}^{2+}$ results in the autophosphorylation of the kinase, which leads to the release of the enzyme from the membrane-cytoskeleton complex (Saitoh and Schwartz, 1985). Furthermore, Saitoh and Schwartz (1985) and Miller and Kennedy (1986) have observed that the activity of the phosphorylated kinase becomes independent of $\mathrm{Ca}^{2+}$. Miller and Kennedy (1986) have also found that the autophosphorylation of the kinase is relatively slow, and they argued that the conversion of a significant proportion of the kinase into the phosphorylated form requires prolonged increases in the intracellular concentration of $\mathrm{Ca}^{2+}$, which may occur in neurons after long or repeated bursts of electrical activity; such a situation may be simulated in our case by the $\mathrm{K}^{+}$induced depolarization. We propose, therefore, that the depolarization-induced $\mathrm{Ca}^{2+}$ influx mimics the effect of the stimulation of $N$-methyl-D-aspartate and/or other excitatory amino acid receptors and leads to autophosphorylation of the $\mathrm{CaM}$ kinase. A proportion of the phosphorylated enzyme is translocated to sites such as the nucleus, where it functions in an activated form, despite the maintenance of physiological free $\mathrm{Ca}^{2+}$ levels in the whole cell, and elicits long-term changes in nuclear and cytoplasmic functions that result, ultimately, in the survival of granule cells in vitro.

\section{References}

Baker, R. E., A. M. M. C. Habets, E. Brenner, and M. A. Corner (1982) Influence of growth medium, age in vitro and spontaneous bioelectric activity on the distribution of sensory ganglion-evoked activity in spinal cord explants. Dev. Brain Res. 5: 329-341.

Beale, R., G. R. Dutton, and D. N. Currie (1980) An ion flux assay of action potential sodium channels in neuron- and glia-enriched cultures of cells dissociated from rat cerebellum. Brain Res. 183:241246.

Bennett, M. R., and W. White (1981) The survival and development of cholinergic neurons in potassium-enriched media. Brain Res. 173: 549-553.

Betz, H. (1983) Regulation of $\alpha$-bungarotoxin receptor accumulation in chick retina cultures: Effects of membrane depolarization, cyclic nucleotide derivatives, and $\mathrm{Ca}^{2+}$. J. Neurosci. 3: 1333-1341.

Black, I. B. (1978) Regulation of autonomic development. Annu. Rev. Neurosci. 1: 183-224.

Blaustein, M. P. (1975) Effects of potassium, veratridine and scorpion venom on calcium accumulation and transmitter release by nerve terminals in vitro. J. Physiol. (Lond.) 247: 617-655.

Brenneman, D. E., E. A. Neale, W. H. Habig, L. M. Bowers, and P. G. Nelson (1983) Developmental and neurochemical specificity of neuronal deficits produced by electrical impulse blockade in dissociated spinal cord cultures. Dev. Brain Res. 9: 3-27.

Burton, K. (1956) A study of the conditions and mechanisms of the diphenylamine reaction for the colorimetric estimation of DNA. Biochem. J. 62: 315-323.

Chalazonitis, A., and G. D. Fishbach (1980) Elevated potassium induces morphological differentiation of dorsal root ganglionic neurones in dissociated cell culture. Dev. Biol. 78: 173-183.

Changeux, J.-P., and A. Danchin (1976) Selective stabilization of developing synapses as a mechanism for the specification of neuronal networks. Nature 264: 705-712.

Crain, S. M., M. B. Bornstein, and E. R. Peterson (1968) Maturation of cultured embryonic CNS tissues during chronic exposure to agents which prevent bioelectric activity. Brain Res. 8: 363-372.

Cull-Candy, S. G., and D. C. Ogden (1985) Ion channels activated by L-glutamate and GABA in cultured cerebellar neurones of the rat. Proc. R. Soc. London [Biol.] 224: 367-373.

Currie, A. N., and G. R. Dutton (1980) $\left.{ }^{3} \mathrm{H}\right] \mathrm{GABA}$ uptake as a marker for cell type in primary cultures of cerebellum and olfactory bulb. Brain Res. 100: 473-481.

Dunlop, D. S., W. van Elden, and A. Lajtha (1977) Developmental effects on protein synthesis rates in regions of the CNS in vivo and in vitro. J. Neurochem. 29: 939-947.

Edelman, G. M. (1984) Modulation of cell adhesion during induction, histogenesis, and perinatal development of the nervous system. Annu. Rev. Neurosci. 7: 339-377.

Gallo, V., M. T. Ciotti, A. Coletti, F. Aloisi, and G. Levi (1982) Selective release of glutamate from cerebellar granule cells differentiating in culture. Proc. Natl. Acad. Sci. USA 79: 7919-7923.

Gallo, V., R. Balázs, and O. S. Jørgensen (1985) Cell surface proteins of cerebellar interneurones and astrocytes cultured in chemically defined and serum-supplemented media. Dev. Brain Res. 17: 27-37.

Harris, W. A. (1981) Neural activity and development. Annu. Rev. Physiol. 43: 689-710.

Hefti, F., H. Gnahn, M. E. Schwab, and H. Thoenen (1982) Induction of tyrosine hydroxylase by nerve growth factor and by elevated $\mathrm{K}^{+}$ concentrations in cultures of dissociated sympathetic neurons. J. Neurosci. 2: 1554-1566.

Hof, R. P., U. T. Ruegg, A. Hof, and A. Vogel (1985) Stereoselectivity at the calcium channel: Opposite action of the enantiomers of a 1,4 dihydropyridine. J. Cardiovasc. Pharmacol. 7: 689-693.

Holton, J. B. (1977) The investigation of inherited disorders of amino acid metabolism using the Rank Hilger Chromaspek. Med. Technol. 11: 31-38.

Ishida, I., and T. Deguchi (1983) Effect of depolarizing agents on choline acetyltransferase and acetylcholine esterase activities in primary cell cultures of spinal cord. J. Neurosci. 3: 1818-1823.

Jørgensen, O. S. (1981) Neuronal membrane D2-protein during rat brain ontogeny. J. Neurochem. 37: 939-946.

Kingsbury, A., V. Gallo, P. Woodhams, and R. Balázs (1985) Survival, morphology and adhesion properties of cerebellar interneurones cultured in chemically defined and serum supplemented medium. Dev. Brain Res. 17: 17-25.

Kingsbury, A., V. Gallo, and R. Balázs (1986) Dihydropyridine $\mathrm{Ca}^{2+}$ agonists are potent stimulators of $\mathrm{Ca}^{2+}$ uptake and transmitter release in cultured cerebellar granule cells. Biochem. Soc. Trans. 14: 11361137.

Klausner, R. D., M. C. Fishman, and M. J. Karnovsky (1979) Ionophore A23187 disrupts membrane structure by modifying protein lipid interactions. Nature 281: 82-83.

Lasher, R. S., and I. S. Zagon (1972) The effect of potassium on neuronal differentiation in cultures of dissociated newborn rat cerebellum. Brain Res. 41: 428-488. 
Lowry, O. H., N. J. Rosebrough, A. L. Farr, and R. J. Randall (1951) Protein measurement with the Folin phenol reagent. J. Biol. Chem. 193: 265-275.

MacDermott, A. B., M. L. Mayer, G. L. Westbrook, S. J. Smith, and J. L. Barker (1986) NMDA-receptor activation increases cytoplasmic calcium concentration in cultured spinal cord neurones. Nature 321: $519-522$

Meier, E., C. M. Regan, and R. Balázs (1984) Changes in the expression of a neuronal surface protein during development of cerebellar neurones in vivo and in culture. J. Neurochem. 43: 1328-1335.

Miller, R. J., and S. B. Freedman (1984) Are dihydropyridine binding sites voltage sensitive calcium channels? Life Sci. 34: 1205-1221.

Miller, S. G., and M. B. Kennedy (1985) Distinct forebrain and cerebellar isoenzymes of type II Ca ${ }^{2+} /$ calmodulin-dependent protein $\mathbf{k i}$ nase associate differentially with the postsynaptic density fraction. J. Biol. Chem. 260: 9039-9046.

Miller, S. G., and M. B. Kennedy (1986) Regulation of brain type II $\mathrm{Ca}^{+} /$calmodulin-dependent protcin kinase by autophosphorylation: $\mathrm{A} \mathrm{Ca}^{2+}$-triggered molecular switch. Cell 44: 861-870.

Model, P. G., M. B. Bornstein, S. M. Crain, and G. D. Pappas (1971) An electron microscopic study of the development of synapses in cultured fetal mouse cerebrum continuously exposed to xylocaine. J. Cell Biol. 49: 362-371.

Nishi, R., and D. K. Berg (1981) Effects of high potassium concentrations on the growth and development of ciliary ganglion neurons in cell culture. Dev. Biol. 87: 301-307.

Patel, N. J., J. Cohen, and R. Balázs (1984) Protein synthesis in cells isolated from the developing rat cerebellum. Int. J. Dev. Neurosci. 2: 287-299.

Phillipson, D. T., and M. Sandler (1975) The influence of nerve growth factor, potassium depolarization and dibutyryl(cyclic) adenosine $3^{\prime}, 5^{\prime}$ monophosphate on explant cultures of chick embryo sympathetic ganglia. Brain Res. 90: 273-281.

Preuss, K. C., G. J. Gross, H. L. Brooks, and D. C. Waltier (1985) Slow-channel calcium activators, a new group of pharmacological agents. Life Sci. 37: 1271-1278.

Rogg, H., L. Criscione, A. Truog, and M. Meier (1985) In vitro comparative studies of the calcium-entry activators YC-170, CGP 28392, and BAY K 8644. J. Cardiovasc. Pharmacol. 7 (Suppl. 6): S31-S37.
Saitoh, T., and J. H. Schwartz (1985) Phosphorylation-dependent subcellular translocation of a $\mathrm{Ca}^{2+} /$ calmodulin-dependent protein kinase produces an autonomous enzyme in Aplysia neurons. J. Cell Biol. 100: 835-842.

Scott, B. S. (1971) Effect of potassium on neuron survival in cultures of dissociated human nervous tissue. Exp. Neurol. 30: 297-308.

Scott, B. S. (1977) The effect of elevated potassium on the time course of neuron cell survival in cultures of dissociated dorsal root ganglia. J. Cell Physiol. 91: 305-316.

Scott, B. S., and K. C. Fisher (1970) Potassium concentration and number of neurones in cultures of dissociated ganglia. Exp. Neurol. 27: $16-22$.

Selak, I., S. D. Skaper, and S. Varon (1985) Pyruvate participation in the low molecular weight activity for CNS neurons in glia-conditioned media. J. Neurosci. 5: 23-28.

Siesjö, B. K. (1981) Cell damage in the brain: A speculative synthesis. J. Cereb. Blood Flow Metab. 1: 155-185.

Syková, E. (1983) Extracellular $\mathrm{K}^{+}$accumulation in the central nervous system. Prog. Biophys. Mol. Biol. 42: 135-189.

Thangnipon, W., A. Kingsbury, M. Webb, and R. Balázs (1983) Observations on rat cerebellar cells in vitro: Influence of substratum, potassium concentration and relationship between neurones and astrocytes. Dev. Brain Res. 11: 177-189.

Tsien, R. W. (1983) Calcium channels in excitable cell membranes. Annu. Rev. Physiol. 45: 341-381.

Walicke, P. A., and P. H. Patterson (1981) On the role of $\mathrm{Ca}^{2+}$ in the transmitter choice made by cultured sympathetic neurones. J. Neurosci. $1: 343-350$

Walicke, P., R. Campenot, and P. Patterson (1977) Determination of transmitter function by neuronal activity. Proc. Natl. Acad. Sci. USA 74: 5767-5771.

Wiesel, T. N., and D. H. Hubel (1963) Effects of visual deprivation on morphology and physiology of cells in the cat's lateral geniculate body. J. Neurophysiol. 26: 978-993.

Zurgil, N., and N. Zisapel (1984) Calcium uptake and calcium-dependent phosphorylation during development of rat brain neurons in cultures. Dev. Brain Res. 13: 293-303. 